\title{
Investigations of Kaolin Clay Collapse Behavior Using an Oedometer Apparatus
}

\author{
Musbah A. Hasan*, Gumaa Abdelazizi Hasan \\ Department of Civil Engineering, College of Engineering, Sirte University, Libya \\ DOI: https://doi.org/10.21467/proceedings.4.14 \\ * Corresponding author email: abormila@gmail.com
}

\begin{abstract}
Geotechnical engineers face serious problems when construction sites contain collapsible soils, which are known by their strength when dry and experience sudden excessive settlement when inundated. Response-to-wetting oedometer tests can be used to obtain estimates of collapse settlements of structures founded on collapsible soil deposits. Generally, the collapsibility of soils is governed by the amount of water within the sample and the magnitude of the applied pressure. In this paper, an experimental study was performed, by using the one-dimensional compression test (single and double oedometer tests), to investigate the effect of the change in initial water content (IWC) and void ratio on the collapse potential of kaolin clays upon wetting. The test results confirmed that, the collapse potential value decreases with the decrease of initial void ration at a low vertical load increment. However, for the samples with different initial water content, the increase of initial water content leads to a decrease of the collapse potential values.
\end{abstract}

Keywords: Collapse potential, Kaolin clay, Water content, Void ratio, Oedometer test.

\section{Introduction}

When the soil has a collapsible grain structure, it can be defined as a soil that can resist moderately large applied stresses with a low value of settlement at a small amount of water content. However, a significant reduction in volume can be observed with the increase of water content, as the applied stresses remain constant. Collapsibility is limited not only to cohesive soils, but also to some cohesionless soils and constructed fills, where the collapse can occur suddenly as a result of the increase of moisture content, as the total vertical stress remains constant (M. Reznik, 2007). As is known, the density of soil plays a main role in the effect of soil collapsibility; i.e. porous fills and soils collapse once it is subjected to loads smaller than the denser fills or soils. However, in many countries, it appears, according to some official documents such as that of Rookovodstvo (1977), that the engineers and designers focus only on the effect of moisture content on soil collapsibility. The document (Rookovodstvo, 1977) designates the value of moisture content and vertical loads at which the loaded soil starts collapsing, as initial collapse moisture content and initial collapse pressure respectively. Once

(C) 2018 Copyright held by the author(s). Published by AIJR Publisher in Proceedings of First Conference for Engineering

Sciences and Technology (CEST-2018), September 25-27, 2018, vol. 2 .
This is an open access article under Creative Commons Attribution-NonCommercial 4.0 International (CC BY-NC 4.0) license, which permits any non-commercial use, distribution, adaptation, and reproduction in any medium, as long as the original work is properly cited. ISBN: 978-81-936820-6-7 
Investigations of Kaolin Clay Collapse Behavior Using an Oedometer Apparatus

the applied load exceeds the initial collapsible pressure specified for particular values of water content and void ratio, the collapse of soil can be noticed. (Vilaret al., 1998) studied the collapse behaviour of a compacted lateritic soil by using the conventional loading-wetting oedometer tests and suction-controlled tests. The influence of dry unit weight, moulding water content and overburden stress on collapse strains is analyzed, and it is shown that the drier samples were the most susceptible to collapse upon wetting. The bearing capacity of collapsible soils decreased to about $50 \%$ due to soaking process, hence, the author recommends using twice the factor of safety stated in different codes to account the soaking effect in collapsible soils. The bearing capacity of collapsible soils when compacted to $95 \%$ of its dry density is larger than that of natural soil by about $24-30 \%$. For both undisturbed and compacted soil samples, as the initial water content increases the collapse potential of soil decreases (K.E.Gaaver 2012). For the same moisture content, the collapse potential decreases when increasing the degree of compaction. Conversely, it increases in the case of soils where the percentage in fine particles is high. Also, with the same energy of compaction, the collapse decreases when increasing the moisture content and this is valid for water, and oil. Conversely, it grows in the case of soils containing more fines. The collapse by water flooding is the fastest and the most accentuated more than that oil. This is valid for all energies of compaction and moisture contents and at any moment (Rachid et al., 2010). Pre-wetting with applying the dynamic compaction at the same time will result in higher efficiency for the compaction. The determination of the most favourable moisture content is required, because the compaction of soils at upper moisture contents can lead to liquefaction, which can cause stopping of volume reduction (Kenneth et al., 1993).

\section{Experimental Programe}

Nine one-dimensional oedometer tests were performed on compacted soil specimens in order to study the influence of initial water content (IWC) and the initial void ratio on collapsibility of kaolin clay. In addition, specimens were saturated at different applied stresses and the amount of collapse deformation was measured.

Table 1. Laboratory testing program

\begin{tabular}{|c|c|c|c|c|}
\hline Test type & $\begin{array}{r}\text { Test } \\
\text { Number }\end{array}$ & $\begin{array}{l}\text { Initial Water } \\
\text { Content w (\%) }\end{array}$ & $\begin{array}{l}\text { Saturated } \\
\text { at }\end{array}$ & $\begin{array}{l}\text { Void Ratio } \\
\text { (e) }\end{array}$ \\
\hline \multirow{6}{*}{$\begin{array}{c}\text { Double } \\
\text { Oedometer test }\end{array}$} & 1 & 10 & - & 2 \\
\hline & 2 & 10 & $5 \mathrm{KPa}$ & 2 \\
\hline & 3 & 10 & - & 1.7 \\
\hline & 4 & 10 & $5 \mathrm{KPa}$ & 1.7 \\
\hline & 5 & 20 & - & 2 \\
\hline & 6 & 20 & $5 \mathrm{KPa}$ & 2 \\
\hline \multirow{3}{*}{$\begin{array}{c}\text { Single } \\
\text { Oedometer test }\end{array}$} & 7 & 10 & $100 \mathrm{KPa}$ & 2 \\
\hline & 8 & 10 & $100 \mathrm{KPa}$ & 1.7 \\
\hline & 9 & 20 & $100 \mathrm{KPa}$ & 2 \\
\hline
\end{tabular}




\subsection{Physical properties of soil}

Tests were performed on specimens of kaolin clay to determine its physical properties. The kaolin clay was supplied by Whitfield \& Son Ltd., England. Properties of the material were obtained according to (BS) standard. Compaction tests on the soil samples were carried out in accordance with the Standard Proctor test procedure, BS 1377. The maximum dry unit weight of kaolin clay was found to be $15.58 \mathrm{kN} / \mathrm{m} 3$ and the corresponding optimum moisture content was about $23.8 \%$. Determination of the distribution of the silt/clay particles was achieved using a hydrometer test, BS 1377. Table 2. summarizes the recorded geotechnical properties obtained from liquid limit, plastic limit, hydrometer, specific gravity and compaction tests. Also, the tested soil sample was classified as (MH) according to the Unified Soil Classification System (USCS).

Table 2. Physical properties of kaolin clay:

\begin{tabular}{|c|c|c|c|c|c|c|c|}
\hline $\begin{array}{l}\text { Liquid } \\
\text { limit: \% }\end{array}$ & $\begin{array}{c}\text { Plastic } \\
\text { limit: } \\
\%\end{array}$ & $\begin{array}{l}\text { Specific } \\
\text { gravity }\end{array}$ & $\begin{array}{c}\text { Silt } \\
\text { fraction: } \\
\%\end{array}$ & $\begin{array}{c}\text { Clay } \\
\text { fraction: } \\
\%\end{array}$ & $\begin{array}{c}\text { Soil } \\
\text { classification }\end{array}$ & $\begin{array}{c}\text { Maximum } \\
\text { dry } \\
\text { density, } \\
\gamma_{d m a x} \\
\left(\mathbf{k N} / \mathbf{m}^{3}\right)\end{array}$ & $\begin{array}{c}\text { Optimum } \\
\text { water- } \\
\text { content: } \\
\%\end{array}$ \\
\hline 0.08855 .0 & 31.4 & 2.64 & 58 & 42 & MH & 15.57 & 23.8 \\
\hline
\end{tabular}
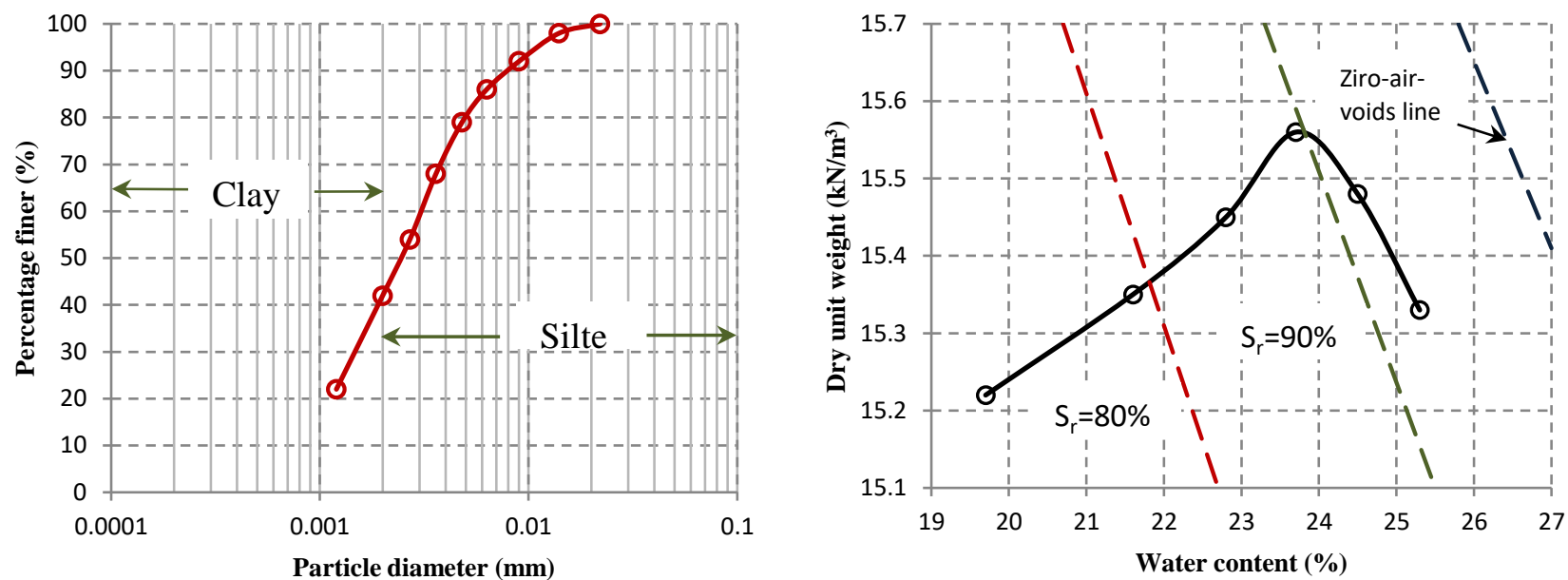

Figure 1. Kaolin clay particle size distribution curve

Figure 2. Standard Proctor compaction

curve

\subsection{Sample preparation}

Soil specimens of kaolin clay were prepared by compacting moist soil, having a predetermined water content of (10 and $20 \%)$ and an initial void ratio of (1.7 and 2), into an oedometer apparatus metal ring as shown in Figure 3. The soil was compacted into the metal ring using a small hammer. Change in the specimen initial water content, when the test is running, was prevented by cealing the odometer cell with a plastic sheet as illustrated in Figure 4. For the

Proceedings of First Conference for Engineering Sciences and Technology (CEST-2018), vol. 2 
present investigation four groups of soil specimens were prepared, each group has a certain initial water content and void ratio. Table 1 shows the initial condition of the soil specimens.
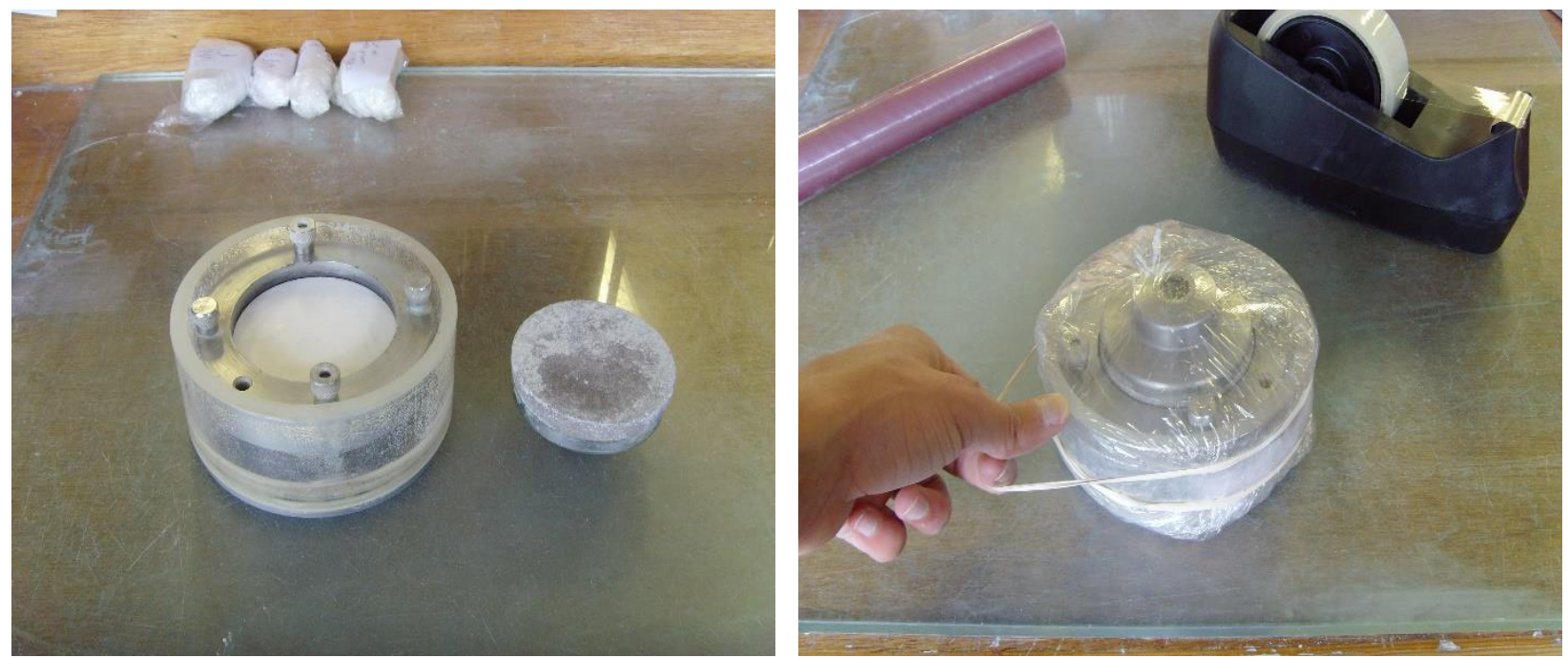

\subsection{Oedometer Test Procedure:}

A mass of kaolin clay is placed in the oedometer ring and allowed to reach equilibrium under a small hunger load. A series of load increments (5, 25, 50, 100 and $200 \mathrm{KPa}$ ) were applied and the dial gauge reading is recorded at the beginning and after equilibrium is reached for each load increment. The next load is applied and the changing of dial gauge reading is recorded once the entire consolidation is achieved. Inundation of the tested samples is taken place at 5 and $100 \mathrm{kPa}$ load increment for double and single oedometer tests respectively. In this paper, the determination of collapse potential was calculated by taking the difference in volumetric strain (\%) between the as-compacted and inundated specimens using Equation (1), by conducting the double and single oedometer tests considering different soil conditions in terms of the moisture content and void ratio, (BS 1377: Part 5: 1990).

$$
C P=\left(\frac{e_{i}-e_{f}}{1+e_{o}}\right)
$$

Where $C P=$ the collapse potential, $e_{o}=$ the initial void ratio, $e_{i}=$ the void ratio caused by the applied load at constant water content and $e_{f}=$ the void ratio caused by the applied load after saturation.

\section{Results and Discussion}

\subsection{Influence of initial water content}

Figure 5 compares the compression curves of double oedometer tests at different initial water contents (IWC) of (10 and 20\%). Soil specimen inundated at $5 \mathrm{kPa}$ and subsequently loaded in the soaked condition up to $200 \mathrm{kPa}$. The magnitude of collapse in the specimen when (IWC 
$=10 \%)$ is higher than that when (IWC $=20 \%$ ). Where, the reduction in void ratio at vertical stress of $100 \mathrm{kPa}$ was about $39 \%$ higher when the initial water content increases from 10 to $20 \%$. Figure 6 shows a similar comparison between compression curves using a single oedometer test for two moist kaolin clay specimens inundated at $100 \mathrm{kPa}$. On wetting, the specimens collapse would increase approximately $(28 \%)$ as the initial water content decreased from 20 to $10 \%$ at a vertical stress of $100 \mathrm{kPa}$. This could be attributed to, a portion of the fine-grained fraction of the soil exists as bonding material for the larger-grained particles. These bonds undergo local compression in the small gaps between adjacent grains. Therefore, these soils compress slightly at low moisture contents due to increase of pressures.
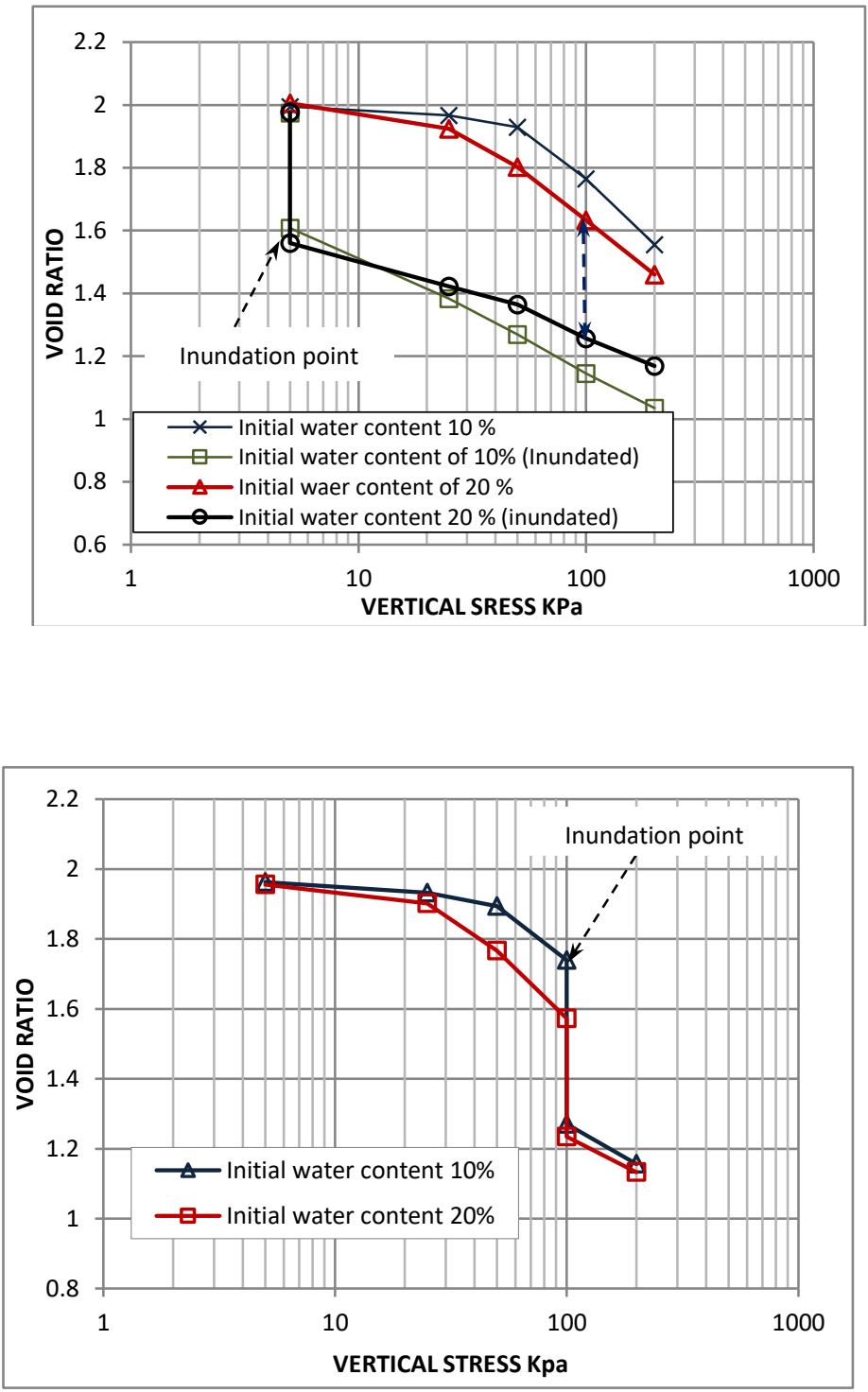

Proceedings of First Conference for Engineering Sciences and Technology (CEST-2018), vol. 2 474 
Investigations of Kaolin Clay Collapse Behavior Using an Oedometer Apparatus

When a collapsible soil is allowed to moisture, the fine binder that is providing the bonding mechanism between the large-grained particles will soften, weaken, and/or dissolve to some extent. Therefore, increasing the value of initial water content leads to the bonding materials start to gradually deteriorate. Consequently, a part of these bonds will undergo an earlier destruction prior to inundation.
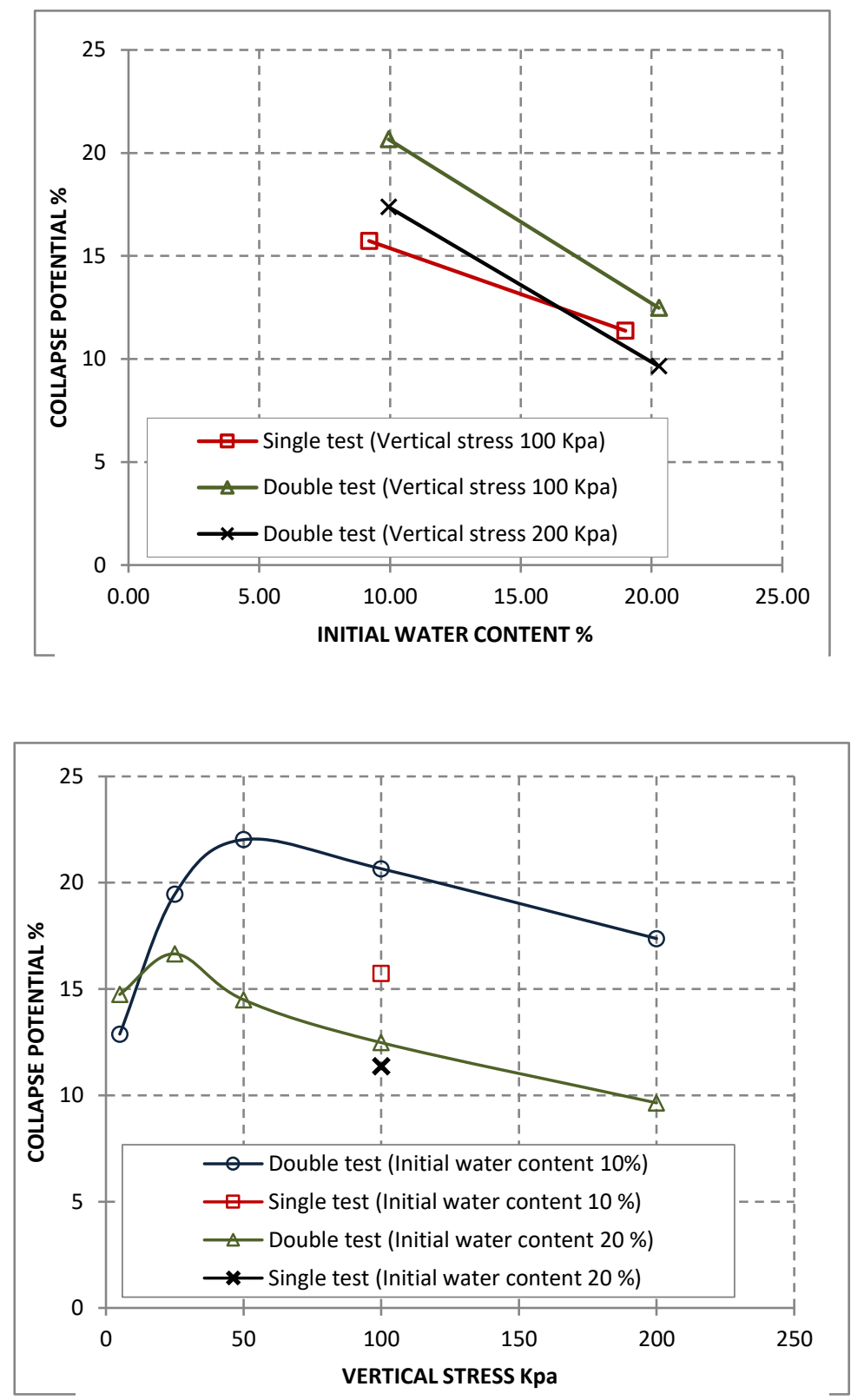

Figure 7 presents the relation between collapse potential (CP) and initial water content (IWC) of kaolin clay sample. At higher values of vertical stress, the magnitude of collapse potential, 
would record a significant decreasing when the initial water content is increased. Considering a double oedometer test, at a vertical stress of $100 \mathrm{KPa}$, the collapse potential decreases from $20.65 \%$ to $12.47 \%$ as the initial water content increases from 10 to $20 \%$. According to (Jennings et al 1975), the severity of the problem changes from severe trouble to very severe trouble based on the decrease in initial water content. Furthermore, results of variation of collapse potential versus vertical stress are expressed in Figure 8.

Compressing the specimens under constant initial void ratio of 2 and various initial water contents of (10 and 20\%) will result in different values of (CP) as the magnitude of compression force varies. The curve representing the double oedometer test with initial water content of $10 \%$ shows that, the highest collapse potential value was observed at $50 \mathrm{KPa}$ load increment $(\mathrm{CP}=22.025)$. The collapse potential starts increasing with the increase of loads until it reaches its maximum value at a critical pressure (pre-consolidation pressure): "pressure at which collapse of a soil begins and the soil changes its response from low to high compressibility" (Phien-wej's et al., 1992) of 50KPa; then it begins to decrease with the increase of the loads being continued. Comparing this curve to the curve obtained from a similar test, having the value of initial water content increased to $20 \%$, a significant reduction of collapse potential is observed. Also, the influence of test type, (single and double oedometer tests), was investigated to compare the results of collapse potential at a certain load increment. Figure 8 shows that, the value of collapse potential, obtained from single oedometer test, was always lower than that obtained from double oedometer test. Where, $(\mathrm{CP}=15.73 \%)$ for single oedometer test and $(\mathrm{CP}=20.66 \%)$ for double oedometer test under the same nominal stress of $100 \mathrm{KPa}$ and initial water content of $10 \%$. This could be attributed to that, friction forces acting along the interfaces between soil specimens and oedometer ring may not decrease to the same degree during single oedometer testing as it could happen if soil specimens were inundated prior to stress application in double oedometer test. Furthermore, it is easier to inundate the unloaded soil specimens (Y.M.Reznik 2000). In addition, the difference between the results obtained from single oedometer test and double oedometer test decreases as the initial water content increases.

\subsection{Influence of initial void ratio}

Figures 9 and 10 show that, the decrease in void ratio upon wetting is quite small at the beginning of the loading process; however, it starts increasing rapidly with the increase of vertical loads being continued. The collapse potential values also increase with the increase of vertical loads upon wetting, where it starts from $(\mathrm{CP}=6.7 \%)$, which means trouble, at $(5 \mathrm{KPa})$ vertical stress, to end up with $(\mathrm{CP}=27.10 \%)$ which means a very severe trouble, at $(200 \mathrm{KPa})$ vertical stress as shown in Figure 11. Also the single oedometer test results show that, the value of collapse potential, at a certain point of a $100 \mathrm{KPa}$ load increment, increases from $(\mathrm{CP}=15.73 \%)$ to $(\mathrm{CP}=18.89 \%)$ by reducing the value of void ratio from 2 to 1.7 . This proves the fact that, the collapse potential, for kaolin clay soil, increases with the decrease of the initial

Proceedings of First Conference for Engineering Sciences and Technology (CEST-2018), vol. 2 476 
Investigations of Kaolin Clay Collapse Behavior Using an Oedometer Apparatus

void ratio at later stages of load increment. This was observed when the same sample subjected to a double oedometer test show in Table (1) [tests (1 and 2) and (3 and 4)], where $(\mathrm{CP}=20.65 \%)$ from tests $(1$ and 2$)$ at $100 \mathrm{KPa}$ vertical stress and $(\mathrm{CP}=25.91 \%)$ from tests $(3$ and 4) at the same vertical stress.
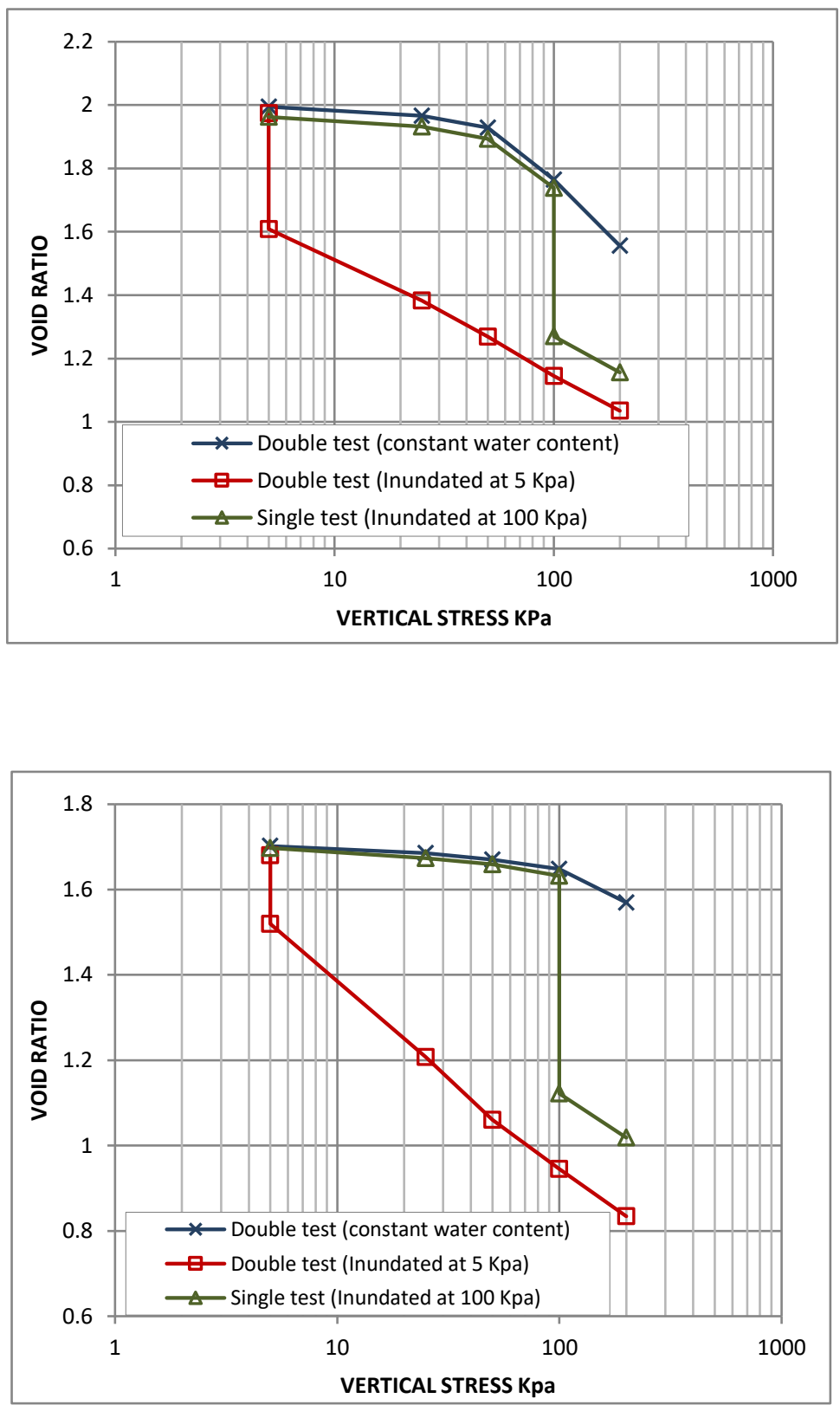

In Figure 11 and 12, a comparison, between the results obtained from double and single oedometer tests, is drawn in order to investigate the effect of the change in void ratio, from 2 
to 1.7 with constant initial moisture content of about $10 \%$, on the collapse potential of kaolin clay. It is observed that, the collapse potential values obtained when considering a void ratio of 2 are higher than those obtained using a void ratio of 1.7 at vertical loads of ( 5 and $25 \mathrm{KPa}$ ) and constant water content of $10 \%$. However, a further increase in the vertical stress results in the opposite of that, where the values of collapse, potential obtained from both tests, become bigger for higher vertical stresses of $(50,100$, and $200 \mathrm{KPa})$ as shown in Figure 12. The reason for that might be that the rearrangement of kaolin clay particles for a specimen with a high initial void ratio is faster than a specimen with lower initial void ratio, under loads being increasingly added, for the same specimen volume and initial water content. Therefore, from Figure 11, the sample with an initial void ratio of (2) becomes more compacted and stable than the sample with an initial void ratio of (1.7) after load increment of (50KPa). This leads to the collapse potential for the sample with an initial void ratio of (2), starting to decrease after exceeding this point, because a high percentage of compaction occurred in earlier stages of load increment as shown in Figure 10. Whereas, the other sample, a low percentage of compaction has occurred in earlier stages of load increment Figure 9, so that the (CP) value keeps increasing after exceeding the point of $50 \mathrm{KPa}$ vertical load. Accordingly, the outcome of this comparison is that the collapse potential value decreasing with the decrease of the initial void ratio under low values of vertical stress (earlier stages of load increment).

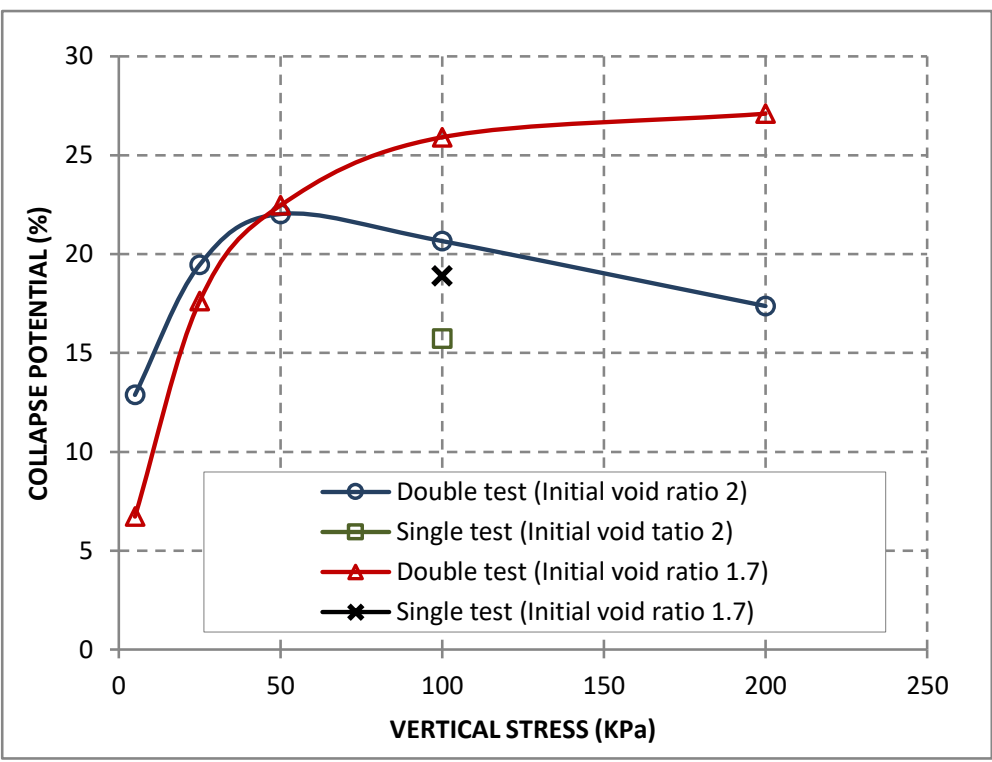

Proceedings of First Conference for Engineering Sciences and Technology (CEST-2018), vol. 2 


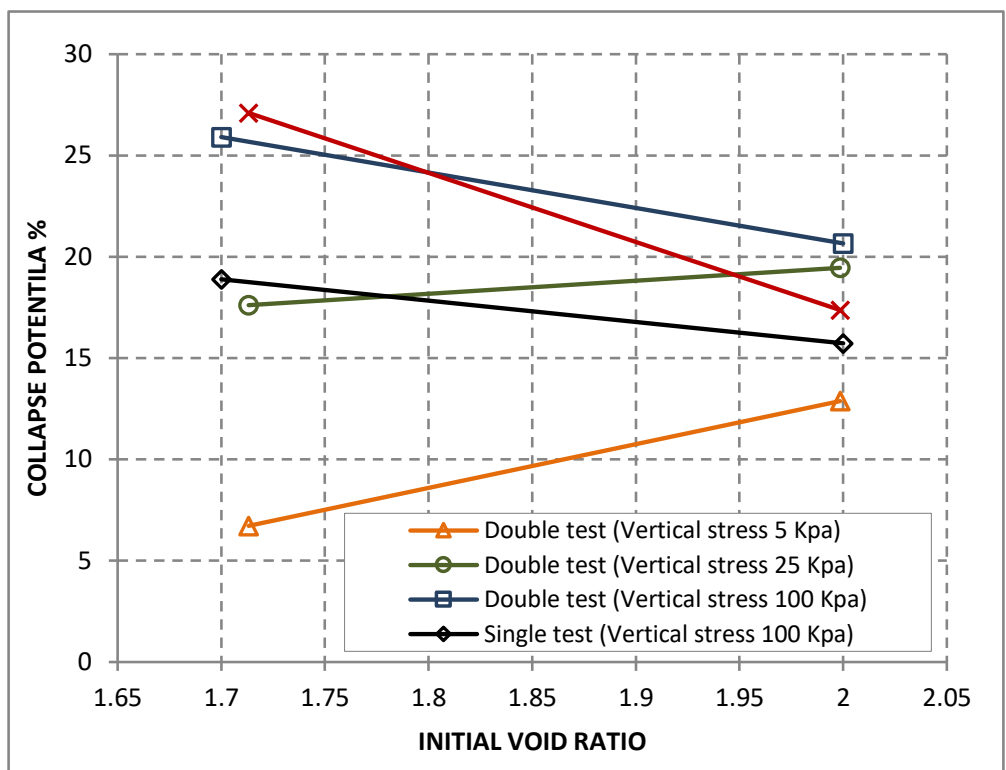

\section{Conclusions}

1) Under a low in situ water content (w.c. $=10 \%$ ) and void ratio of 2 the kaolin clay soil will pose a very severe trouble upon wetting (the collapse potential index at $50 \mathrm{kPa}$ is as high as $22.03 \%$ ). However, rising the initial water content (IWC) as high as $20 \%$, resulting in a reduction in the collapse potential index to $14.49 \%$.

2) At an initial water content of $10 \%$ and constant void ratio of 2 , a considerable difference between the collapse potential index obtained from double and single oedometer tests is observed when subjected to a vertical load increment of $100 \mathrm{KPa}$. However, this difference will decrease as the initial water content increases at the same vertical load increment and void ratio.

3) the collapse potential values obtained when considering a void ratio of 2 are higher than those obtained using a void ratio of 1.7 at vertical loads of ( 5 and $25 \mathrm{KPa}$ ) and constant water content of $10 \%$. However, a further increase in the vertical stress results in the opposite of that, where the values of collapse potential index obtained from both tests, become bigger for higher vertical stresses of (50, 100, and 200KPa).

\section{References}

[1] British Standards Institution. Methods of Test for Soils for Civil Engineering Purposes.

[2] J.E. Jennings, K. Knight, A guide to construction on or with materials exhibiting additional settlements due to collapse of grain structure, in: Proceedings, Sixth Regional Conference for Africa on Soil Mechanics and Foundation Engineering, Johannesburg, 1975, pp. 99-105. 
[3] Jennings, J.E. and Knight, K. (1975) "A guide to construction on or with materials exhibiting additional settlement due to collapse of grain structure". Proceedings 6th African Conference on Soil Mechanics and Foundation Engineering. $99-105$.

[4] Kenneth D. Walsh, William N. Houston, and Sandra L. Houston. Evaluation of in-place wetting using soil suction measurements. J. Geotech. Engrg. 119, 862 (1993).

[5] Khaled E. Gaaver. Geotechnical properties of Egyptian collapsible soils. Alexandria Engineering Journal (2012).

[6] Phien-wej, N., Pientong, T., Balasubramaniam, A.S. In: collapse and strength in characteristics of loess in Thailand, Engineering Geology vol. 32. Elsevier Science, Amsterdam, pp. 59-72. 1992.

[7] Rachid Benkadja, Brahim Belouahri. Influence of Oil on the Magnitude and Rate of Collapsible Soils. Journal of Civil Engineering Research and Practice, Vol. 7 No.1, April 2010, pp. 1 - 12

[8] Reznik, Y.M. Engineering approach to interpretation of oedometer tests performed on collapsible soils. Engineering Geology Vol 57, Issues 3-4, Pages 205-213 (July 2000)

[9] Reznik, Y.M., 1994a. Evaluation of collapse potential using singleoedometer test results. Bulletin of the Association of EngineeringGeologists XXXI (2), 255-261.

[10] Reznik, Y.M., 1994b. Comment: Evaluation of collapse potential using single oedometer test results. Bulletin of the Association of Engineering Geologists XXXI (3), 279.

[11] Vilar, O.M., Machado, S.L. and Bueno, B.D.S. Collapse Behavior of a Compacted Lateritic Soil; 1998.

[12] Yakov M. Reznik, influence of physical properties on deformation characteristics of collapsible soils. Engineering Geology, vol. 92, pp 27-37, (2007).

[13] Lawton, E. C., Fragaszy, R. J., and Hetherington, M. D. (1992). "Review of wetting-induced collapse in compacted soil.” J. Geotech. Eng., 118(9), 1376-1394 